\title{
"With Liberty and Justice for All”? A Look at Criminal Justice in America when the Blindfold is Removed* Craig Muhammad
}

\section{INTRODUCTION}

This essay will provide a glimpse into a system of criminal justice that was founded on the egalitarian principles of integrity, rehabilitation and public safety. Nevertheless, as noble as the motives of the Quakers may have been when they devised the concept of the penitentiary, prisons have evolved into a behemoth system that is undergirded by the cancer of injustice, mass incarceration, over-incarceration, and corporate greed - based on race and income - at the expense of the most marginalized American citizens. Consequently, American citizens are incarcerated in unprecedented numbers that have never before been heard of in the annals of world history.

\section{AMERICA: WORLD LEADER OF INCARCERATION}

In 2007, America reached a milestone in its state and federal prison population with approximately 1.6 million men and women incarcerated (Office of Justice Programs, Bureau of Justice Statistics, Prisoners in 2009). The number of prisoners in America's prisons and jails exceeded 2.3 million (Bureau of Justice Statistics, 2009). In addition, on any given day in the United States, at least 5 million people are on parole and probation (Bureau of Justice Statistics, 2014). Moreover, in 2013 there were 54,148 juveniles confined in placement facilities (Office of Juvenile Justice and Delinquency Prevention, 2015). In 2015, America's prison population stands at an alarming 25 percent of the world's prison population - even though the population of the United States is only 5 percent of the world's human population (Hee Lee, 2015). The "land of the free" incarcerates more of its citizens than France, Belgium and England combined (International Centre for Prison Studies, 2015). And although China has a population that exceeds that of the United States by over one billion people, the prison population of the USA is greater than that of Communist China (The International Centre for Prison Studies, 2015). 


\section{PRISON VIOLENCE: THE CONSEQUENCE OF ABANDONING REHABILITATIVE STRATEGIES}

As a result of privatization and the disregard for rehabilitative strategies, constructive activities that a prisoner could employ toward rehabilitation and transformation are almost extinct. Consequently, prisons across America have become more violent as idleness and overcrowding increase.

In 2008, state Senator Verna Jones and Delegate Christopher Shank of the Maryland General Assembly submitted to Governor Martin O'Malley an interim report from a task force that was studying violence in Maryland prisons. The report was almost a year overdue and the recommended solutions were superficial (Jones and Shank, 2008). Approximately a year before the task force was formed, a corrections officer was murdered in the Maryland House of Corrections in Jessup (Morgan, 2006). In the months leading up to the officer's death, several other officers had been injured and at least three prisoners had been murdered at the same facility (ibid.).

In 2007, Chen and Shapiro conducted a national study on prison violence. Their study was titled: "Do harsher prison conditions reduce recidivism? A discontinuity-based approach". The conclusion of their research yielded results that continue to be ignored - that idleness, overcrowding, prolonged lockdowns, and a lack of concrete programming is the root of prison violence and the high rate of recidivism. These cuts have taken place even though many credible studies on prison violence and recidivism concluded that a lack of programming and other proactive measures encourage an atmosphere of violence and a revolving door policy (Chen and Shapiro, 2007). Moreover, while prison program funding has been drastically cut, program services run by volunteers (that are of no cost to taxpayers) are often discouraged by many prison administrators. Many proponents of this "lock them up and throw away the key" approach do not live in the inner city neighborhoods where many prisoners will be returning one day when they are released. For example, the majority of prisoners on Rikers Island in New York come from conditions so poverty stricken that they cannot even afford bail. In addition, the state of Maryland incarcerates more people from the blighted Sandtown-Winchester area of West Baltimore than from any other region in the state (Fenton, 2008). The Sandtown-Winchester area only consists of approximately 72 square blocks, occupies 0.406 square 
miles. Within that small space, 34.4 percent of the residents live below the poverty level (Wenger, 2015).

\section{PRISONS FOR PROFIT}

America's burgeoning prison population is fuelled, in part, by profit hungry corporations such as Corrections Corporation of America and GEO Group, Inc., leaders in the multi-billion dollar for-profit prison industry. Private prison corporations manage public prisons at a substantial reduction of costs to states and municipalities. However, Adam Gopnik notes, "the interest of private prisons lies not in the obvious social good of having the minimum necessary number of inmates, but in having as many as possible, housed cheaply as possible" (Whitehead, 2012).

Privatization is not relegated to entire prisons being co-opted by private corporations. Under the pretense of "saving money", many prisons have privatized sectors of their day-to-day operations such as the commissary and the medical department, which has resulted in skyrocketing prices for basic hygiene items and a decrease in the quality of medical care.

The private prison industry makes huge financial contributions to political candidates and exerts tremendous political influence. In the wake of the U.S. Supreme Court's decision in "Citizens United", those contributions are now unlimited "to make sentencing laws more severe with a clear intent to drive up the prison population", says former Kansas Secretary of Corrections Roger Werholtz (Whitehead, 2012). Despite the fact that overall crime in America has been on the decline, the nation's incarceration rate has tripled since 1980.

An ordinary person may see the for-profit prison industry as a typical case of capitalism at work. However, the industry is fuelled by inordinate greed that pollutes the integrity of the criminal justice system. For example, a 2009 criminal investigation of the Mid-Atlantic Youth Service Corporation revealed that the company paid two Pennsylvania judges over \$2.6 million to send juveniles to their private prison facilities. The two judges involved in the scheme, Michael Conahan and Mark Ciavarella, pleaded guilty and received 28 years and 17 years in prison respectively (NBC News, 2015).

Today, even homelessness is criminalized as governments across the nation pass more laws prohibiting begging, loitering and sleeping in public places that ensures more homeless Americans are arrested, prosecuted and 
incarcerated. "No matter what the politicians or corporate heads might say, prison privatization is neither fiscally responsible nor in keeping with principles of justice. It simply encourages incarceration for the sake of profit", says attorney John W. Whitehead, founder and president of The Rutherford Institute and author of "The Freedom Wars" (Whitehead, 2012).

\section{RACIAL DISPARITIES IN SENTENCING PRISONERS TO LIFE IMPRISONMENT AND THE OVER-INCARCERATION OF PRISONERS SERVING LIFE SENTENCES}

Research indicates that as a prisoner gets older the chance of recidivism decreases tremendously (Justice Policy Institute, 2009). Research also shows that the likelihood of a released prisoner being re-arrested decreases with an increase in time served prior to release in the community with support (PEW, 2012). Of the 1.6 million men and women incarcerated in prisons, many of them are at least fifty years of age, have been incarcerated for at least three decades, and their propensity to re-offend is slim. The above category also includes prisoners that are serving life sentences - many of whom have redefined the meaning of remorse, redemption, transformation and rehabilitation. Over 160,000 prisoners are serving life sentences in the U.S. (The Sentencing Project, 2015). Those numbers also include a disproportionate number of African-Americans.

In 2009, The Sentencing Project reported that the percentage of AfricanAmericans serving "life with parole" and "life without parole" sentences stood at 48.3 percent and 56 percent, respectively. At the same time, Hispanics serving "life with parole" and "life without parole" sentences stood at 17 percent and 7.4 percent, respectively. Out of all 50 states that presently have prisoners serving life sentences, southern states and MasonDixon states have some of the highest prison populations of persons serving life sentences (The Sentencing Project, 2009). Maryland, long considered to be within the orbit of southern political influence, has the highest proportion of Blacks serving life sentences than any other state in the Union (The Sentencing Project, 2009). More than three-quarters of the state's lifers are Black (76.7 percent), compared to the national average of 48.3 percent. In 2009 , the only state outside the immediate southern sphere with a lifer prison population above 65 percent was Illinois. The justice 
system in Illinois has a history of being so skewed that in 2003, in a speech delivered at Northwestern University of Law in Illinois, Governor George Ryan outlined his plan to commute the death sentences of every prisoner on Illinois' death row. Governor Ryan felt duty-bound to take unprecedented action after scores of the state's capital cases had been reversed for a new trial or sentencing. In dozens of other capital cases, condemned prisoners were completely exonerated. The miscarriage of justice was so blatant that Governor Ryan, echoing Supreme Court Justice Harry Blackmum's words in a 1994 dissent against the death penalty said, "From this day forward, I shall no longer tinker with the machinery of death" (Death Penalty Information Center, 2003). The Sentencing Project (2009) also reported that 84 percent of Maryland's juveniles who are serving life sentences are Black. According to 2009 estimates, the overall top five states, by percentage, with juveniles serving life sentences who are Black are Maryland (84 percent), Alabama (84 percent), Virginia (81 percent), South Carolina (76.4 percent) and Louisiana (72.9 percent) (The Sentencing Project, 2009).

\section{THE POLITICIZATION OF LIFE SENTENCES IN MARYLAND}

The public is unaware of the politics that stand between confinement and release of an incarcerated American citizen serving a life sentence, particularly in Maryland. For example, over 2,300 prisoners are serving life sentences in Maryland. However, Maryland is just one of two other states (Oklahoma and California) where an independent parole board can only recommend parole for someone serving a parolable life sentence. The final decision is made by the Governor (Maryland General Assembly, 1993). Consequently, "life with parole" sentences have become politicized into death sentences because no governor wants his political career to hang in the balance of a lifer being released from prison and possibly committing another offense - even though, nationally, prisoners serving "life with parole" sentences have the lowest recidivism rate of any group of released prisoners (The Sentencing Project, 2009).

A 2004 analysis by The Sentencing Project found that, historically, upon release people sentenced to life were much less likely to be rearrested within three years, compared to other groups of released prisoners (Mauer et al., 2004). The low recidivism for lifers is partly due to the average amount of 
time that a lifer serves on a life sentence, which is 25 years. Nevertheless, as a result of the politicizations of life sentences, particularly in Maryland, hundreds of prisoners that have been recommended for release by the Maryland Parole Commission are languishing in prison. Their chances for release are bleak.

There is a gross misunderstanding surrounding prisoners sentenced to life terms. Most of them are serving life sentences "with the possibility of parole". Meaning, that when a judge handed down their term of confinement, it was done so with the possibility in mind that one day there would be a merit-based movement towards the prisoner's release on parole. Also, the public is often under the impression that prisoners serving parolable life sentences have been convicted of committing the most heinous and egregious criminal acts. In some case that is true and any crime committed against an individual or the community deserves punishment. However, there are thousands of prisoners convicted of committing similar crimes as a lifer, but are serving less than a life sentence. There are also many incarcerated citizens serving parolable life sentences because they refused a plea agreement for a lesser sentence, opted to exercise their constitutional right to trial, and were found guilty and sentenced to "life with the possibility of parole" as a consequence of being found guilty by a judge or jury. In many states, particularly in Maryland, statutory law and sentencing guidelines give judges no other recourse but to sentence a defendant to a life term if he/she is convicted by a jury of a crime that carries a maximum life sentence. In addition, many prisoners sentenced to life terms come from very poor economic backgrounds. Consequently, they could not afford to hire a private attorney. Unfortunately, state issued legal representation was their only alternative.

The Founding Fathers of the United States believed that mercy should be an integral part of the administration of justice. A case of mercy worth mentioning is the April 2010 sentencing of Washington County Judge W. Kennedy Boone III. On November 5, 2009 Judge Boone, with a blood alcohol level of 0.18 , more than twice the legal limit, allegedly struck another vehicle that injured two people. A pregnant woman that was a passenger in the car that Boone had hit accused him of causing her to suffer a miscarriage. However, he was never charged in connection with the woman's miscarriage. Judge Boone also had a prior conviction for driving while impaired, dating back to 1985. At his sentencing, District Court Judge Robert C. Wilcox stated, 
"If we all had to answer for mistakes we did 20 years ago it would be a tough sell. We all make mistakes, sometimes stupid mistakes". Judge Boone was given a sentence of three years probation and fined $\$ 1,000$. He ended up violating the terms of his reprimand (The Daily Record, 2011). Nevertheless, it is also obvious from racial and economic disparities in arrests, convictions, sentencing and incarceration that mercy is not granted to people of colour, the poor, and those who are politically weak.

\section{CONCLUSION}

There are two symbols in America that are intended to reflect its uniqueness and greatness: The Statue of Liberty (which mirrors America's unprecedented freedoms) and the Lady Justice who is arrayed in the glory of a simple blindfold (representing equality in the dispensation of justice). Lady Justice's covered eyes are supposed to reflect a criminal justice system that is not prejudiced by the negative influence of politics, racism, economic bias and financial profit. However, America's criminal justice system no longer reflects the values of its symbolic icon or the Founding Fathers. Nevertheless, with all of its imperfections, I believe American citizens have the potential, to once again make criminal justice in America a beacon of light for the world to emulate. Therefore, if mass incarceration and overincarceration are to be eliminated, if racial and economic disparities are to disappear, and if prisons are expected to return to the rehabilitation model - then there is work for us to do. But, if criminal justice in America is allowed to persist on its present course, many marginalized incarcerated citizens will continue to languish in penal institutions in a country whose pledge says, “...with liberty and justice for all”.

\section{ENDNOTES}

* Portions of this article are excerpts from the author's book, From Jericho to Jerusalem: Youth, Street Organizations \& Community Development.

\section{REFERENCES}

Broadwater, L. (2006) "Gangs led to second Jessup Prison killing this month", The Examiner-May 24. 
Bureau of Justice Statistics (2015) Probation and Parole in the United States. Washington (D.C.): U.S. Department of Justice, Office of Justice Programs.

Bureau of Justice Statistics (2009) Prisoners in 2009, Washington (D.C.): U.S. Department of Justice, Office of Justice Programs.

Chen, M. and J. M. Shapiro (2007) "Does Prison Harden Inmates? A Discontinuitybased Approach", American Law and Economics Review, 9(1): 1-29.

Death Penalty Information Center (2003) In Ryan's Own Words: I Must Act, Washington (D.C.): Death Penalty Information Center.

Fenton, J. (2015) Sandtown-Winchester leads State in number of people Incarcerated", The Baltimore Sun - February 26.

International Centre for Prison Studies (2015) World Prison Population (9th Edition), London (UK): International Centre for Prison Studies.

Jones, V. and C. Shank (2008) Interim report for the Task Force to Study Prison Violence in Maryland, Report submitted to Maryland Governor Martin O'Malley.

Justice Policy Institute (2009) The Release Valve: Parole in Maryland, Washington (D.C.).

Lomax, W. and S. Kumar (2015) Still Blocking the Exit, Joint Report from the ACLU of Maryland and the Maryland Restorative Justice Initiative.

Maryland General Assembly (1993) Annotated Code of Maryland, Correctional Services Article §7-301 (4).

Mauer, M., R. S. King and M. C. Young (2004) The Meaning of Life: Long Prison Sentences in Context, Washington (D.C.): The Sentencing Project.

Morgan, K. (2006) "General assembly holds hearings on prison violence", The Baltimore Times - August 24.

NBC News (2015) "Pennsylvania seeks to close books on "kids for cash" Scandal" August 12.

Office of Juvenile Justice and Delinquency Prevention (2012) Statistical Briefing Book, Juvenile Residential Facility Census 2012, Washington (D.C.): U.S. Department of Justice, Office of Justice Programs.

Pew Charitable Trusts [PEW] (2012) Time Served: The High Cost, Low Return of Longer Prison Terms, Washington (D.C.): Pew Charitable Trusts

The Daily Record (2011) "Maryland judge convicted of DWI on leave after violating terms of reprimand", Maryland Daily Record.

The Osbourne Association (2014) The High Cost of Low Risk: The Crisis of America's Aging Prison Population. New York (NY): The Osbourne Association - June 20.

The Sentencing Project (2015) Fact Sheet: Trends in U.S. Corrections, Washington (D.C.): The Sentencing Project.

The Sentencing Project (2009) No Exit: The Expanding Use of Life Sentences in America, Washington (D.C.): The Sentencing Project.

Wagner, J. (2006) "Chief of prison plagued corrections division to retire", The Washington Post - August 24.

Wenger, Y. (2015) "Saving Sandtown-Winchester", The Baltimore Sun - May 10.

Whitehead, J. W. (2012) "Jailing Americans for profit: The rise of the prison industrial complex", Huffington Post - June 10.

Ye Hee, M. (2015) "Does the United States Really have 5 percent of the World's Population and One Quarter of the World's Prison Population?", The Washington Post-April 30. 


\section{ABOUT THE AUTHOR}

Craig Muhammad has been incarcerated for 33 years in the Maryland Department of Public Safety \& Correctional Services. He is a facilitator for the American Friends Service Committee's Friend of a Friend program. He is author of "From Jericho to Jerusalem: Youth, Street Organizations \& Community Development" (Infinity Publishing 2013) and contributing author of "Paper Thin, Soul Deep" (New York: Vantage Press 2002). The author can be reached at:

Craig Muhammed \#166-850/223218

P.O. Box 534

Jessup, Maryland 20794

USA 